$<$ 原 著 $>$

初期高分化型肝癌の血管構築：血流イメージングによる in vivo 解析

\begin{tabular}{|c|c|c|c|c|c|c|}
\hline 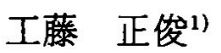 & 冨田 & 周介 ${ }^{1)}$ & 枋尾 & 人司 ${ }^{2)}$ & 濱田 & 充生 ${ }^{2)}$ \\
\hline 純1) & 岡部 & 純弘 11 & 樫田 & 博史 ${ }^{1)}$ & 平佐 & 昌弘 ${ }^{11}$ \\
\hline 康良 ${ }^{1)}$ & 小森 & 英司1) & 織野 & 彬雄 ${ }^{11}$ & 谷 & 友彦3) \\
\hline 建熙3) & 林 & 雅造 ${ }^{4)}$ & 石川 & 稔晃 ${ }^{4)}$ & 白根 & 博文 ${ }^{5)}$ \\
\hline 博也5) & 堂 & 彰男1) & & & & \\
\hline
\end{tabular}

\begin{abstract}
要 旨：切除された腫煌径 $3 \mathrm{~cm}$ 以下の肝細胞癌66結節の5ち病理組織学的に, (1) 結節全体が 均一に高分化型肝癌で占められていたもの14結節，および，(2）高分化型肝癌を内包する腺腫 様過形成と診断された 3 結節，の計17結節を対象に，in vivoにおける血流イメージングの所見 を解析し，初期の高分化型肝癌 (e-HCC)における血管構築の特徵像について検討した． $\mathrm{CO}_{2}$ 動 注 US angiographyにより評価した動脈血流成分は，hypervascular 5 結節，isovascular 5 結 節，hypovascular 4 結節， vascular spot in hypovascular 3 結節であり同時期に切除された 3 cm 以下の古典的な肝癌（ad-HCC）49結節に比し，動脈性 vascularity が低い傾向にあった。 また門脈造影下 CTにて評価した門脈血流は，ad-HCCの全例が perfusion defect を呈するの に対し，e-HCC 14例のうち 5 例が perfusion defect を呈しなかった。 perfusion defect を呈し た群 9 例と呈しなかった群 5 例の結節の腫場径には有意差を認めなかった。をた，e-HCCには 脂肪化の程度の強いものが多く，これら e-HCC の特徵的な血管構筑 (乏血状態) との関連性が 示唆された。
\end{abstract}

索引用語： 初期高分化型肝癌 早期肝癌 US angiography 門脈造影下 CT

\section{I. 緒 言}

近年、小肝細胞癌 (以下 HCC) の切除例の增加に伴 い, 従来の画像診断の常識にあてはまらないHCC 症 例が増加してきている(-4).これらは, 病理学的に高分 化型肝癌であることが多く、“既存の肝構筑を大きくは 破壊していない発癌初期ないし早期の段階の肝 癌5 7”と考えられる。これらいわゆる早期肝癌ないし は初期の高分化型肝癌の血管構築は, 従来の古典的肝 癌と異なっている可能性があり，これを明らかにする ことは，発癌初期の段階の肝癌の診断の面からも，ま た発癌過程や脂肪化の機序等を考察する上でも重要な

1）神戸市立中央市民病院消化器センター内科

2）同 腹部超音波室

3) 同 消化器センター第 1 外科

4) 同 消化器ヒンター第 2 外科

5) 同 病理
問題である. 今回, 我々は，HCC 切除例について，病 理学的に初期高分化型肝癌と考えられる結節について in vivo 血流イメージングを行い腫瘤内の動脈・門脈血 流動態を解析し，その血管構築の特徵像について検討 を行った。

\section{II. 対 象}

1989年 2 月から1991年 7 月の 2 年 6 力月間に切除さ れた最大径 $3 \mathrm{~cm}$ 以下の肝細胞癌60例66結節の5ち, （1）結節全体が均一に高分化型肝癌で占められていた もの14結節および，（2）高分化型肝癌を内包する腺腫 様過形成（HCC in AH）と診断された 3 結節，計17結 節を, 本研究では, 初期の高分化型肝癌 $(\mathrm{e}-\mathrm{HCC})$ と 定義し，これらを対象とした，また中分化型肝癌の混 在を認める49結節については, 古典的肝癌 (ad-HCC) として, e-HCC と対比検討を行った. 年齢は, 46〜77 藏（平均 $54 ） ，$ 男性 42 例，女性18例である。 


\section{III. 方 法}

in vivo 血流イメージングの方法は動脈血流評価は $\mathrm{CO}_{2}$ 動注 US angiography ${ }^{8-101}$ とて門脈血流評価は経 動脈性門脈造影下連続 CT(門脈 CT $)^{11}$ にて行った。 た腫瘍径の計測は，摘出新鮮標本にて行った。

\section{1. 動脈血流評価}

US angiography は $\mathrm{CO}_{2} 10 \mathrm{~m} l$, heparin 加生食 10 $\mathrm{m} l$, 自家血 $5 \mathrm{~m} l$ を agitation mixture により用手的に $\mathrm{CO}_{2}$ microbubble を作成し、肝動脈に插入された力 テーテルより一定の速度で緩徐に注入することにより 行った (平均注入速度 $1 \sim 2 \mathrm{~m} l /$ 秒)，注入量は，超音波 画像上で周囲に充分量の bubble が充満するまでの適 当量とし，特に周囲肝の bubbleにより結節ェュー像 が隠れることのない上う注意し，注入した ${ }^{8 \sim 10)}$.

$\mathrm{CO}_{2}$ microbubbleを注入した後の時相を $\mathrm{CO}_{2}$ microbubble が肝全体に広がるまでの早期相，しばらく停滞 した後に washoutされるまでの中期相, 周囲肝から完 全にwashoutされた後の後期相の 3 時相に分け, 全例 ビデオ録画にて記録し，特に早期中期の時相の血流動 態については, 反復再生にて諳影評価を行った。

US angiography $の$ vascullar pattern は，便宜上 4 型に分類した。すなわち早期，中期，後期のいすれれか の時相に周囲肝上りも結節内の vascularity の高いも のを hypervascular，等しいものを isovascular，低い むの hypovascular, hypovascular の中に vascularityのある spotを認めるものを vascular spot in hypovascular とし，全結節を分類した ${ }^{8)}$. US の使用装置は Aloka SSD 650, 探触子は， $3.5 \mathrm{MHz}$ を 使用した。

\section{2. 門脈血流評価}

結節内の門脈血流動態の評価は, 門脈造影下連続 CT (門脈 CT) にて行った。カテーテルを上腸間膜動 脈に㨂入の後, $0.7 \sim 1.0 \mathrm{~m} l /$ 秒の速度で造影剤 （Iopamiron 300）を注入し，注入開始20３0秒後より table incrementation mode で撮影を行った，撮影条

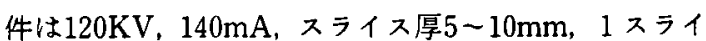
ス3.5秒， 1 回の息止めで 6 10スライス撮影を行い全 肝スキャンに要する時間は80 120秒（14〜18スライ ス)であった。使用装置は GE CT/T 9800である. plain CTであらかじめ結節の部位が明確である場合には全 肝スキャンは行わずその slice 周辺の数 sliceのみに 限定してdynamic scan を行った。 全肝スキャン，部 分スライススキ+ンともにstatic phaseに打いて delayed scanむ行った，門脈血流動態の評価は dynamic phase において，結節内の CT 値が周囲肝よ りも低いものを perfusion defect $(+)$, 周囲肝と等し いものを perfusion defect (ー)とした。

\section{3. 腫瘤内血流動態に上る結節の分類}

結節のるつ血行動態的特徵をより明確にするために 腫瘤内の動脈門脈血流動態によって全結節を 5 群に分 類した1).すなわち門脈血流(十)で動脈血流 hypovascularのものを Type I, 門脈血流（一）で動脈血流 hypovascular の のを Type II, 門脈血流（ー）で動 脈血流 isovascular のものを Type III, 門脈血流(一) で動脈血流 hypervascular のものを Type IV，てして 門脈血流は一部ない儿全体に認められかつ動脈血流は vascular spot in hypovascular pattern を示すものを Type V とした.

\section{4. 統計学的処理}

数值は全て mean $\pm \mathrm{SD}$ で表わし，統計学的有意差の 検定はStudent の $t$-testおよび多群間比較には ANOVA 検定（Scheff のF-test）を用いた。

\section{IV. 成 績}

(1) 睡瘍径

e-HCCの腫瘍径は0.5 2.5cm (mean $\pm \mathrm{SD}=$ $1.53 \pm 0.71 \mathrm{~cm})$ に分布しており，ad-HCCは0.5 3.0 $\mathrm{cm}$ (mean $\pm \mathrm{SD}=1.94 \pm 0.63)$ に分布していた，adHCC の腫煌径の平均值は，e-HCC 上り大きい傾向に あった $(\mathrm{p}<0.05)$ (Table 1).

\section{（2）動脈血流成分}

e-HCC の動脈血流は17例のうち 5 例が hypervascular, 5 例が isovascular, 4 例が hypovascular, 3 例かi vascular spot in hypovascular pattern t呈し た。これに対 し ad-HCC は49例中43例が hypervascular を呈し6例が isovascular を呈した。 ad-HCCで hypovascular $P$ vascular spot in hypovascular patternを呈したものは 1 例む認めなかった (Table 2).

(3) 門脈血流成分

門脈血流を評価し得たものは e-HCC 17例中14例, ad.HCC 49例中37例であった。

e-HCC 14例中 perfusion defectを呈したものは 9

Table 1 Characteristics of the Subjects.

$\left.\begin{array}{l|c|c|c}\hline & n & \begin{array}{c}\text { Tumor Size } \\ (\mathrm{cm})\end{array} & \text { Fatty Change } \\ \hline \text { e-HCC } & 17 & 1.53 \pm 0.71- & 41 \%(7 / 17)- \\ \text { ad.HCC } & 49 & 1.94 \pm 0.63\end{array}\right]$.

$* p<0.05$ 
Table 2 Arterial Vascularity Evaluated by US angiography.

\begin{tabular}{l|c|c}
\hline & e-HCC & ad-HCC \\
\hline hypervascular & 5 & 43 \\
isovascular & 5 & 6 \\
hypovascular & 4 & 0 \\
vascular spot in hypovascular & 3 & 0 \\
\hline \multicolumn{1}{c|}{ Total } & 17 & 49 \\
\hline
\end{tabular}

Table 3 Portal Perfusion Evaluated by CT During Arterial Portography.

\begin{tabular}{c|c|c}
\hline & e-HCC & ad-HCC \\
\hline defect $(+)$ & 9 & 37 \\
defect $(-)$ & 5 & 0 \\
\hline & 14 & 37 \\
\hline
\end{tabular}

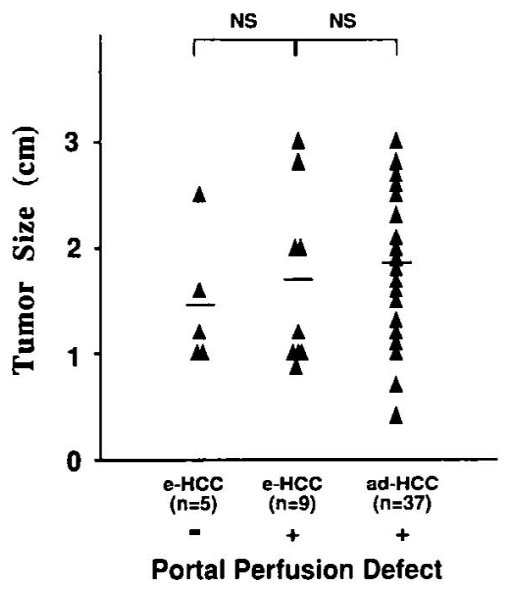

Fig. 1 Relationship between tumor size and portal perfusion defect on CT during arterial portography. Mean size of early stage hepatocellular carcinomas (HCCs) without portal perfusion defect is not significantly different from that of early HCCs with portal perfusion defect or that of advanced HCCs with portal perfusion detect.

例, perfusion defectを呈しなかったるのは 5 例で あった。これに対し ad-HCC 37例住全例が perfusion defect を呈した(Table 3). ad-HCCで defect として 描出された最小の結節は $5 \mathrm{~mm}$ 大であった。

perfusion defect $(+)$ の-HCC 9 例, perfusion defect $(-)$ の e-HCC 5 例, perfusion defect $(+)$ の ad-HCC 37例の畽瘍径の平均はそれぞれ1.46士
Hemodynamic Characteristics of Early HCCs

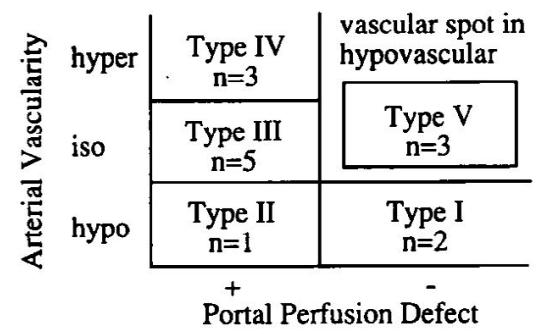

Fig. 2 Hemodynamic pattern of early stage hepatocellular carcinoma were classified into 5 types depending on arterial vascularity and por. tal perfusion.

$0.63 \mathrm{~cm}, 1.61 \pm 0.88 \mathrm{~cm}, 1.89 \pm 0.69 \mathrm{~cm}$ で各群の間に 統計学的有意差を認めなかった Fig. 1).

\section{（4）e-HCC の血管構筑}

動脈・門脈ともに評価可能であった e-HCC 14結節 は, 動脈血流の vascularity おょび門脈血流の perfusionの有無により5型に大別された”(Fig. 2).14結 節のうちでは Type III すなわち動脈血流成分 isovascular, 門脈血流 defect $(+)$ の群が 5 例と最も多い傾 向にあった（Fig. 3)。その他 Type I (Fig. 4) は 2 例, Type II は 1 例, Type IVは 3 例, Type V (Fig. 5) は 3 例であった。

(5) e-HCCにおける脂肪化

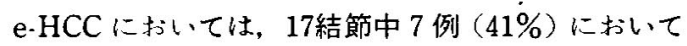
高度の脂肪化を認め, ad-HCCの $8 \%$ と比して有意に 高率であった（Table 1)（Fig. 3).

$$
\text { V. 考 察 }
$$

古典的な肝細胞癌の血管構築は豊富な動脈性腫湯血 管の増生と門脈血流の欠如であることはよく知られて いる事実である ${ }^{12}$. 併来, 肝細胞癌のこの様な血管構築 は, 肝動脈造影によって hypervascular に描出され確 定診断の根拠とされてきたが, 近年の画像診断, 特に US の進歩によりこの様な典型的な血管構築が血管 造影上捉えられない小 HCC 結節が多数経験されるよ らになってきた每,13,14!.これらは，多くの場合，高分 化型肝癌であり，血管造影上は hypervascular に描出 されないことが多い。一方，HCCの前癌病変として近 年注目されている腺腫様過形成 特徵像は動脈血流は hypovascular で門脈血流は, 周 囲肝と同程度に保たれていることである(16)。この様な 血管構築は，通常の血管造影のみでは描出することは 困難でそれゆ穴，HCCとの鑑別を困難なるのとしてい 


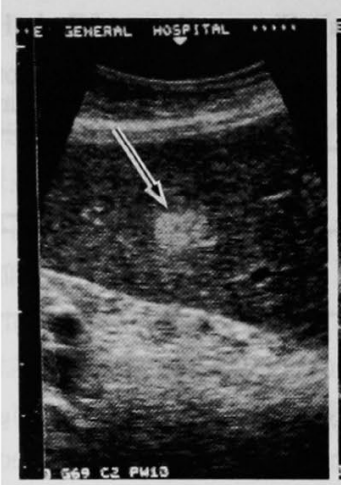

A

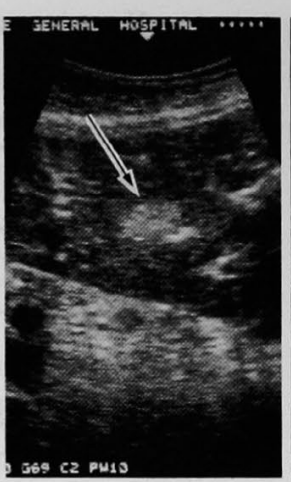

B

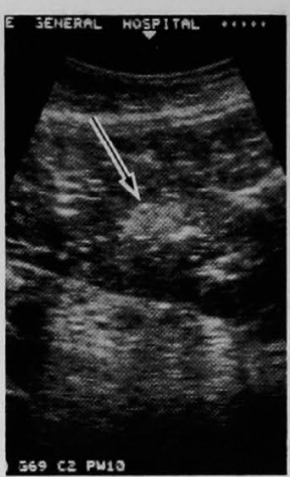

C

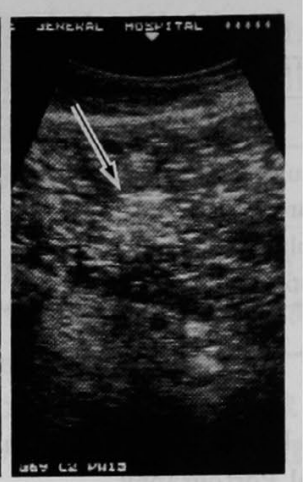

D

A : Plain ultrasonography (US) shows a hyperechoic nodule at the left lateral segment of the liver (arrow). B-D: US angiography reveals the tumor as isovascular (arrows).

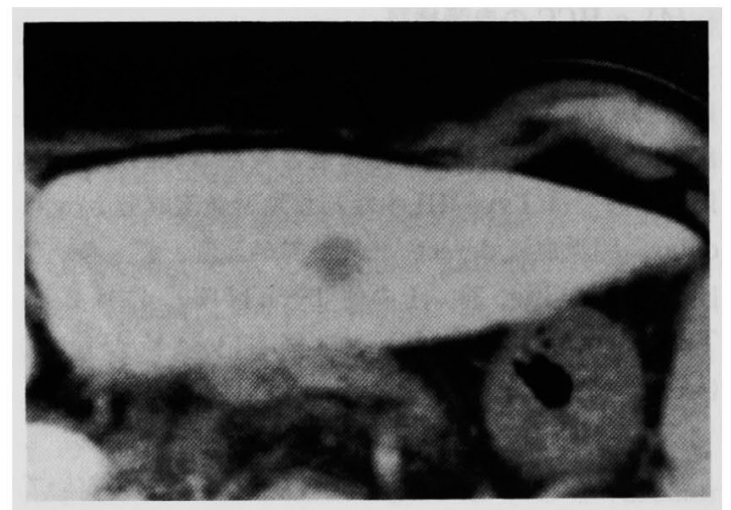

E : Portal perfusion defect is clearly demonstrated at the left lateral segment.

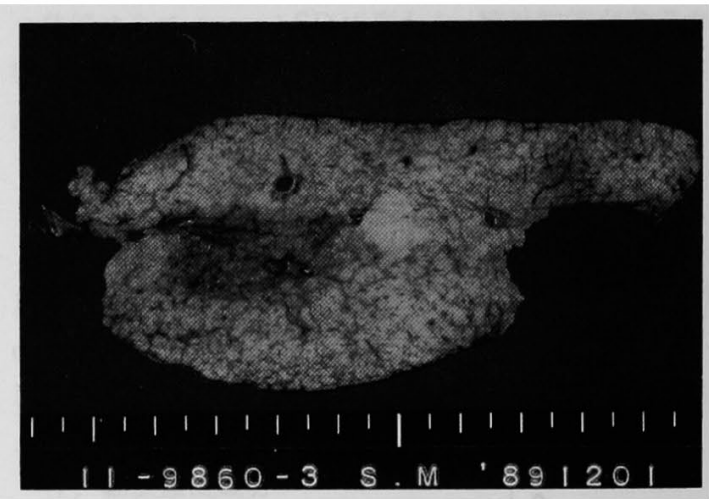

$\mathrm{F}:$ Resected specimen shows the tumor measures $1.0 \mathrm{~cm}$ in diameter.

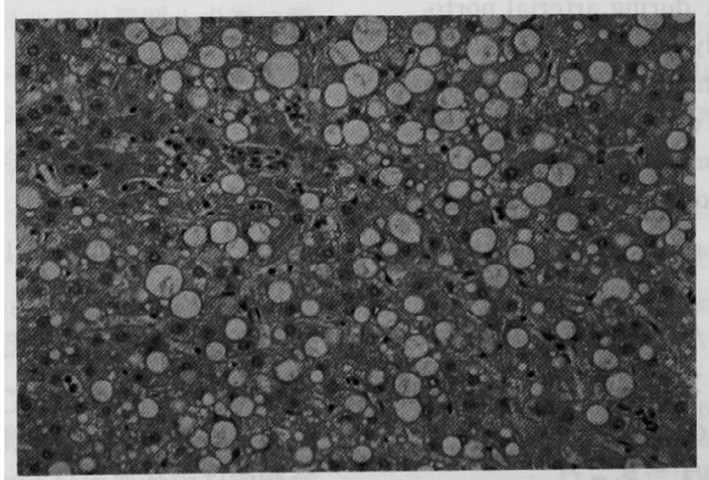

G: Microphotograph shows well-differentiated HCC with fatty metamorphosis uniformly within the nodule, suggesting e-HCC.

Fig. 3 e-HCC (Type III) 


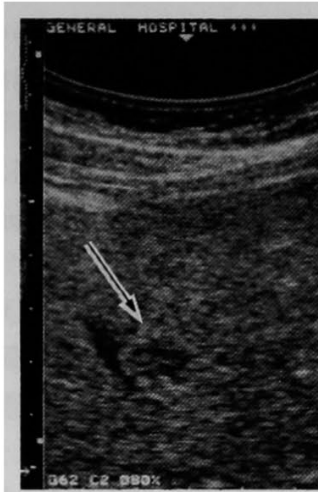

A

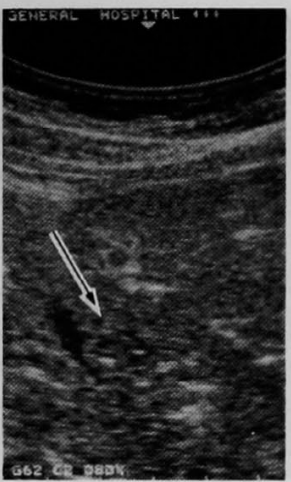

B

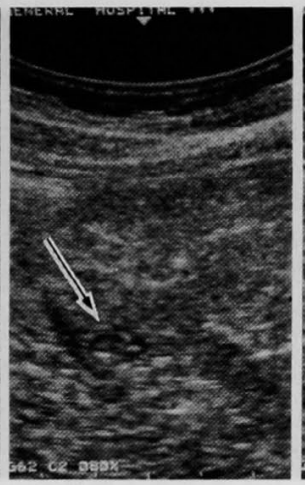

C

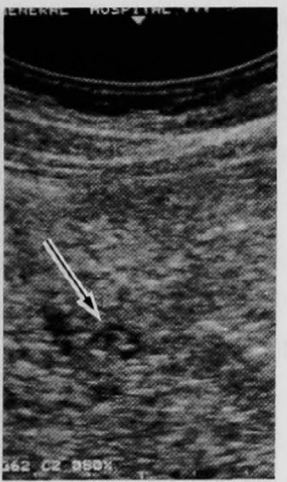

D

A : Plain ultrasonography (US) shows a hypoechoic nodule with bright margin at the left lateral segment of the liver (arrow). B.D: US angiography reveals the nodule as hypovascular (arrows). Portal perfusion defect was not demonstrated on CT during arterial portography (CTAP) (not shown in the Figure).

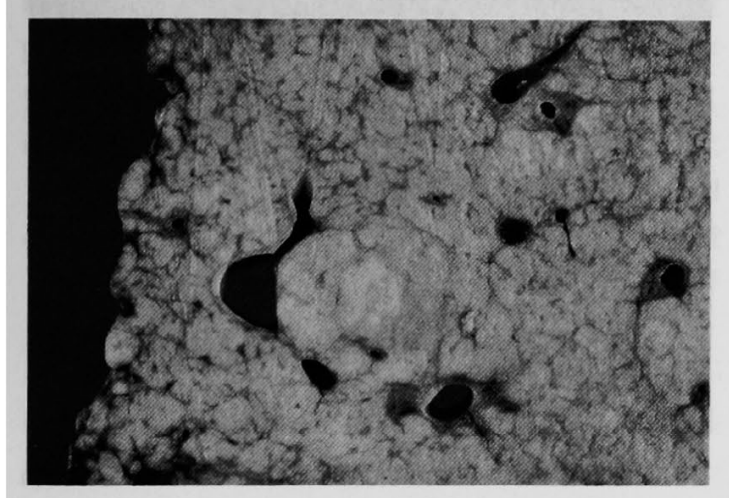

E : Resected specimen shows the nodule measures $1.0 \mathrm{~cm}$ in diameter.

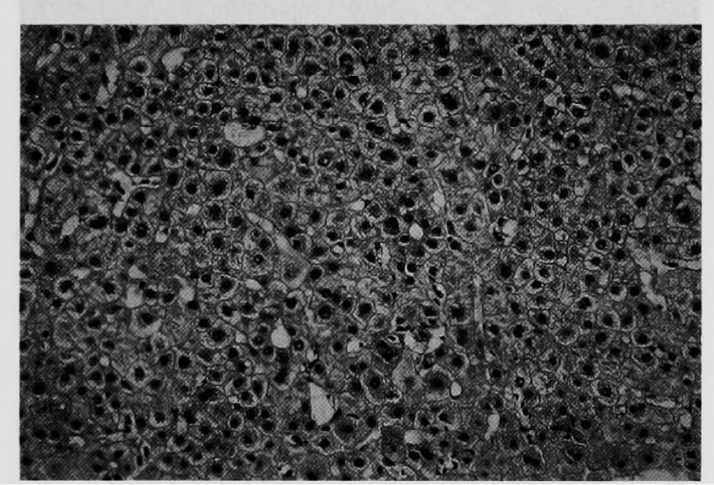

F : Microphotograph of the resected specimen shows well-differentiated HCC. Fatty metamorphosis was seen at the marginal region of the nodule (not shown in the Figure).

Fig. 4 e-HCC (Type I)

る.これまでそのような HCCゃ AH の血管構築は, 摘 出標本, 剖検肝標本を用いた microangiogram ${ }^{16)}$ 拈よ

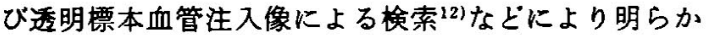
にされてきたものである。るそれに対し，従来は，透明 標本でしか評価し得なかった細な血管構筑を最近の 画像診断の新しい展開によりUSゃCT などの断層画 像と angiography を組み合わせること (US angiogra. phy, CT angiography) により in vivoにおいてその 血管構築をかなり正確に評価することが可能となって

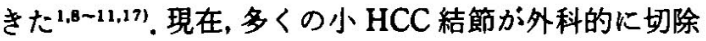

されるようになり，その早期形態像が，主として病理 組織学的な見地から明らかにされつつある゙ ながらそのような病理組織像を呈する HCC の血管構 築については，汪とんど検討されていないのが現状で ある。これは，透明標本による血管構築の解析と組織 診断か同一標本を材料としては，行い得ないといら点 に起因していると考えられる。また従来の血流の解析 法である血管造影法は, conventionalな方法のみでは せいぜい“血管造影上， hypervascularに描出されな い”といら所見が得られるにすぎないからである。こ 

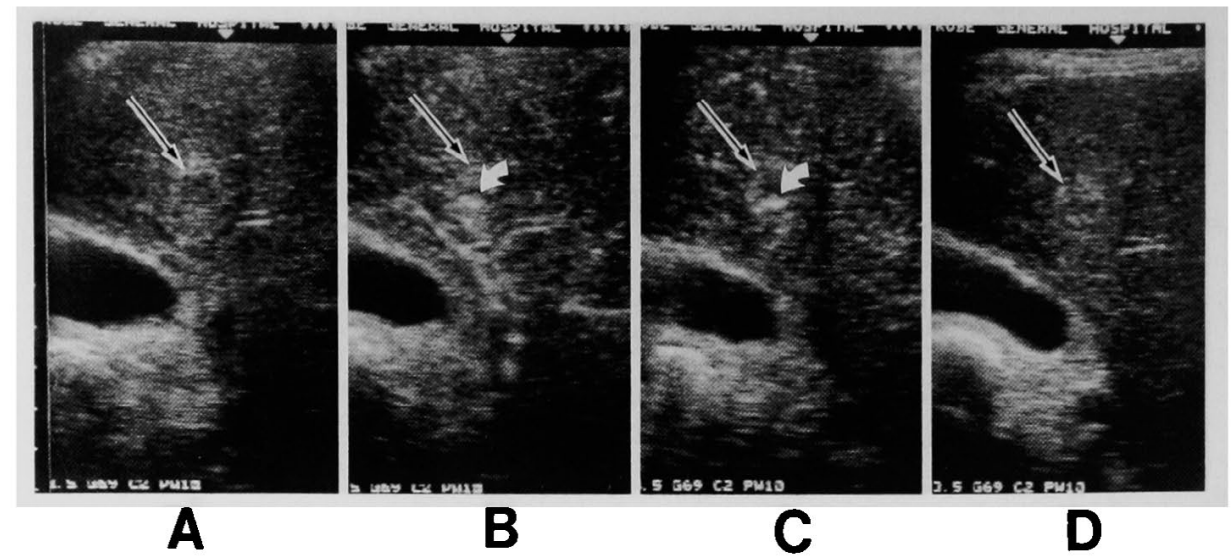

A : Plain ultrasonography (US) shows a hypoechoic nodule with bright margin at the anteroinferior segment of the liver. B-D : Small vascular spot (white arrows) is demonstrated in hypovascular area (arrows) on US angiography. Portal perfusion defect was not revealed on CT during arterial portography (CTAP) (not shown in the Figure).

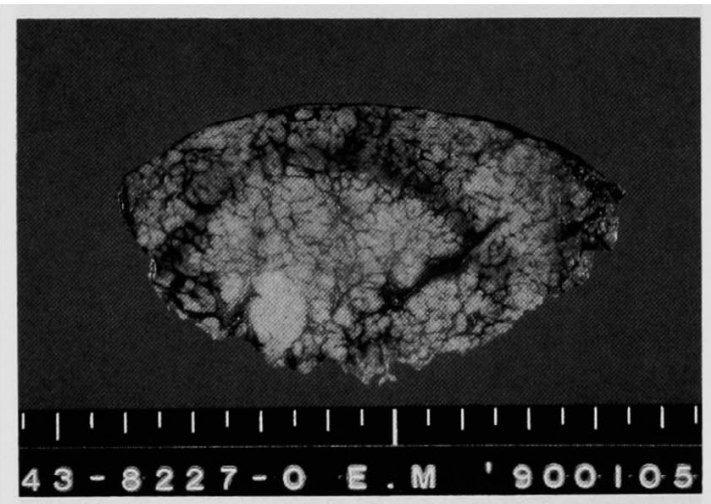

$\mathrm{E}$ : Resected specimen shows an irregular shaped nodule, measuring $1.1 \mathrm{~cm}$ in diameter.

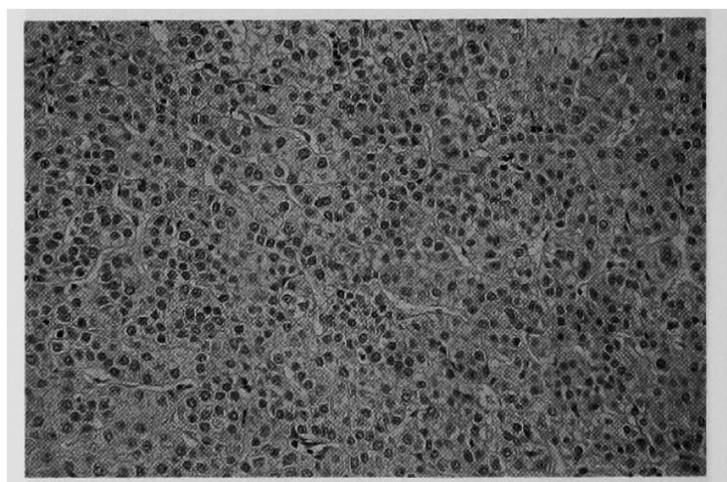

F : Well-differentiated HCC focus is found within the basically benign hyperplastic nodular lesion, suggesting adenomatous hyperplasia containing malignant foci.

Fig. 5 e-HCC (Type V)

のよ5な e-HCCについての病理学的知見の急速な進 歩々血管構築を反映する画像診断法の立ち逢れの間の gapをうずめることは, 肝癌の発癌過程と,それに対応 した血流動態の变化を考察するらえで, あるいはまた， 良悪の画像による鑑別をすすめて行くうえでも重要な 問題であると考えられる.

今回我々は, e-HCCについて, 動脈性の血管構築は, US と angiographyを組又合わせたUS angiogra・

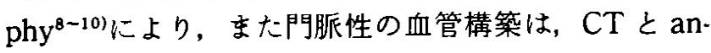
giography を組み合わせた門脈 $C T^{11,271}$ にて詳細に評 価し、検討を行った。その結果, e-HCCの血管構築の
特徵像として以下の点が明らかとなった。すなわち $\mathrm{e}$. HCCにおいては, (1) 動脈性腫煌血管の増生が未発達 なものが多い（2）門脈血流成分の低下していないも のも存在する。（3）動脈す門脈血流も低下した結節も 存在する. (4) HCC in AHの動脈血流所見は, hypovascularな結節内の vascular spot として描出 される.（5）脂肪化を伴っている結節の血管構築は, 動脈血流む門脈血流も低下している結節に多い，とい う5点である。

促来門脈 CTにて perfusion defect を検出し得ない 要因として, 結節内の門脈血流成分の存在以外に検査 
法そのものの限界が指摘されている11,18).すなわち，門 眽 CT の検出限界サイズは, 約 $5 \mathrm{~mm}$ 程度であり, 被検 者の息つぎの問題や partial volume effectなどによ ク，実際には，門脈血流を欠如していても，小結節の 場合, defect 像として捉えられない場合が考えられ る.しかしながら今回の我々の検討では defect 像を呈 した e-HCCの畽湯径と defect 像を呈さなかった eHCCの腫瘍径の間に有意差がみとめられなかった。 の事実は, 腫瘍径 $5 \mathrm{~mm}$ 大でも ad-HCC の如く, 完全に 門脈血流を欠いてる場合は,はっきりと defect 像とし て確認し得るといらことを示していると考えられる。 すなわち,e-HCCにおいては腫漡径が ad-HCC 群とほ とんど変わらないにもかかわらず defect 像が描出さ れないのは，装置や技術的な問題あるいはサイズの問 題上りもむしろ門脈血流が結節内に多かれ少なかれ存 在することに起因していると推測される.

今回の検討において e-HCC の血管構築の特徽像が 明らかとなったが，I型に属する 2 結節は，動脈血流 hypovascular で門脈血流（+）である。これらは，従 来より $\mathrm{AH}$ に特徵的な血管構築とされてきた の成績は, 癌化の発見と, 癌化に伴う血管楧築の変化 とが必ずしも並行して進行せず癌化がおこってもAH の血管構筑が保たれている時期があり得ることを示唆 しているるのと考学られる。松井ら ${ }^{17.191}$ は肝硬变に伴 万結節性病变の悪性度と結節内動脈・門脈血流動態之 がよく相関することを示し，客観的な病理学的鑑別が 困難な症例においててをの血行支配の診断により悪性 度が推定できることを示した。これらの成績は著者ら のその後の同様の検討でも確認され”。I 型いわゆる 門脈血を有し，動脈血に乏しい結節群は，腺腫様過形 成や再生結節などの良性結節が多いことが判明した。 今回我々の示したe-HCCの5ち，門脈 CTにて perfusion defect を示さなかった結節群 5 例のうち I 型 の 2 例については, 血行動態的には AH の血管構筑を 残した結節と考えられ，たとえ癌としても悪性度の低 い発癌して間もない極く初期の HCC と考えられる。 また】型を示す結節群と，門脈血を明らかに久く結節 群は，たと之病理学的には似かよった高分化な肝癌の 形態を呈しても腫揚倍加時間201や悪性度の面では明ら かに異なっており ${ }^{1.17,191} \mathrm{HCC}$ が肝硬変を背景にしてい るかきり I 型の結節群の臨床的な取り扱いについて は，これら血流動態的悪性度を考慮して対応しても上 い結節群と考えられる。これら癌と診断されるI 型の 結節群が，実際の自然経過の面でまた生物学的悪性度
の点で真に門脈血を欠く結節群よりも低いか否か，そ してそれが病理形態的に認識し得る差を有するか否 か、あるいはまた遺伝子 level での差異があるのかな いのかについては，非常に興味のある重要な問題と考 えられ，今後の検討が期待される。

それでは現時点において画像診断, 特に血流イメー ジングにより e-HCCの診断にどの程度迫ることがで きるであろらか．今回示したe-HCCの血管構築は Fig. 2 に示す如く様々な pattern を呈するが，これま での我々の検討では門脈血流を欠く結節は，まず“癌” と診断可能である゙”。た動脈血流評価では, vascular spot in hypovascular を呈せば, HCC in AH もしく は, ad-HCC (Ed II in Ed I) と診断可能であるので “癌”と診断可能である”．従って今回検討した e-HCC 17結節においてはCTおよびUSを angiography と 組み合わせて效密に血管構築を評価することにより e-HCC の $82 \%$ (14/17)に扔いて癌と診断することが可 能であった，癌の確診が困難であったのはI 型の 2 結 節と門脈 CTを行わなかった1結節のみであった。I 型の結節群については，先に述べた如くその生物学的 悪性度の点で根本的に門脈血を欠く結節群に比し低い 可能性もあり，その良悪の鑑別，位置付け，適正な治 療的対応については，今後明確にして行く必要がある。 そのためには，さらに症例を重ね，機能評価としての 血流所見と形態診断としての組織所見を綮密に対比し て行くことが必要であり，さらには病理形態学以外の 遗伝子学的あるいは分子生物学的な良い“むのさし” の出現にも期待したい.

\section{まとめ}

1. e-HCC の血管構築の特徽像について in vivo 血 流イメージングにより娭討を行った。

2. その結果 e-HCCは,

(1) 動脈性 vascularity が低い。

(2) 門脈血流を有する結節も存在する。

（3）動脈血流も門脈血流も低下した結節も存在す る.

(4) $\mathrm{HCC}$ in $\mathrm{AH}$ では vascular spot in hypovascular を呈する.

（5）脂肪化を呈する結節の血管構築は動脈血も門脈 血も低下した結節群に多い。 といら特徵が明らかとなった。

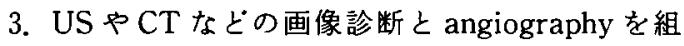
み合わせた緻密な方法で結節性病变の血流動態を評価 することは e-HCC の機能評価の面からの診断や良性 
結節からの癌化の過程等を考察するらえで重要である と考えられた。ささらに詳細に病理組織像との対比や遺 伝子学的な検討と対比させておこならことが重要と考 えられた。

\section{文献}

1）工藤正俊,富田周介, 喍田博史, 他：肝硬变に伴 結節性病変の腫湯内血流動態一癌化の准展 動態との関連についてー，日消誌 88：1554 $-1565,1991$

2）高安賢一，幕内雅敏，広橋説雄，他：肝細胞癌を内 包した adenomatous hyperplasia および境界病 变の画像診断。日消誌 $86: 2404-2412,1989$

3) Yoshimatsu $S$, Inoue $Y$, Ibukuro $K$, et al: Hypovascular hepatocellular carcinoma undetected at angiography and CT with iodized oil. Radiology 171 : 343-347, 1989

4) Sonoda $T$, Shirabe $K$, Takenaka $K$, et al: Angiographically undetected small hepatocellular carcinoma: Clinicopathological characteristics, follow-up and treatment. Hepatology $10: 1003-1007,1989$

5）神代正道：早期肝癌の病理組䅧と発癌様式。消化 器癌 $1: 36-42,1991$

6）広橋説婎：旰の铱小癌とその境界病变の病理.「肝 睡瘍生検と画像. 第 2 巻」, 国際医書出版, $\mathrm{p} 1-12$, 1990

7) Kanai T, Hirohashi S, Upton MP, et al: Pathology of small hepatocellular carcinoma: A proposal for a new gross classification. Cancer $60: 810-819,1987$

8）杤尾人司, 冨田周介, 工藤正俊, 他：血流動態解析 による肝腫瘤の鑑別診断. US angiography の有 用性について。超音波医学 18:327-337, 1991

9) Kudo M, Tomita S, Tochio H, et al : Sonogra phy with intraarterial infusion of carbon dioxide microbubbles (sonographic angiography): Value in differential diagnosis of hepatic tumors. AJR 158 : 65-74, 1992

10) Kudo M, Tomita $S$, Tochio $H$, et al: Small hepatocellular carcinoma: Diagnosis with ultrasound angiography during intraarterial
$\mathrm{CO}_{2}$ microbubbles. Radiology $182: 155-160$, 1992

11) Matsui O, Kadoya $M$, Suzuki $M$, et al: Dynamic sequential computed tomography during arterial portography in the detection of hepatic neoplasms. Radiology 146: 721-727, 1983

12）中島敏郎，神代正道：肝癌の血管構筑。「肝紐胞 癌：病理アトラス」, 第 5 章, シュプリンガー・フェ フラーク，東京，p107ー116, 1986

13) Takayasu $K$, Shima $Y$, Muramatsu $Y$, et al: Angiography of small hepatocellular carcinomas : Analysis of 105 resected tumors. AJR $147: 525-529,1986$

14）工藤正俊, 冨田周介, 杤尾人司, 他：小肝細胞癌の 動脈性 vascularity 之組織所見。 $\mathrm{CO}_{2}$ 動注 US angiography および切除標本による検討. 肝臟 26 ： 1008-1016, 1991

15) Takayama $T$, Makuuchi $M$, Hirohashi $S$, et al : Malignant transformation of adenomatous hyperplasia to hepatocellular carcinoma. Lancet $336: 1150-1153,1990$

16) Sasaki $K$ : Adenomatous hyperplasia in liver cirrhosis: An approach from a microangiographical point of view. Gann Monogr Cancer Res $25: 127-140,1980$

17) Matsui $O$, Kadoya $M$, Kameyama $T$, et al: Benign and malignant nodules in cirrhotic livers: Distinction based on blood supply. Radiology 178 : 493-497, 1991

18) Merine $\mathrm{D}$, Takayasu $\mathrm{K}$, Wakao $\mathrm{F}$ : Detection of hepatocellular carcinoma: Comparison of CT during arterial portography with $\mathrm{CT}$ after intraarterial injection of iodized oil. Radiology $175: 707-710,1990$

19）松井修，角谷真澄，吉川淳，他：肝硬変に伴 5 結節性病变の画像所見. 画像による悪性度の推定. 腹部画像診断 $10: 1020-1029,1990$

20）杤尾人司, 畐田周介, 工藤正俊, 他：US angiogra phy でそ血性を示す旰細胞癌及びその境界病変の 四場発育速度. 門脈血流の有無との関連について。 契音波医学 18:742-748, 1991 


\title{
Hemodynamic characteristics of early stage hepatocellular carcinoma: In vivo evaluation with vascular imagings
}

\author{
Masatoshi KUdo"), Shusuke Tomita ${ }^{1)}$, Hitoshi Tochio ${ }^{21}$, Michio HaMada ${ }^{21}$, Jun Mimura ${ }^{11}$, \\ Yoshihiro OKaBE ${ }^{1)}$, Hiroshi Kashida", Masahiro HIRASA ${ }^{1)}$, Yasuyoshi IBUKI", \\ Hideshi KoMORI", Akio ORINO"1), Tomohiko TANI ${ }^{31}$, Tatehiro KaJIWARA', \\ Masazou HaYASHI ${ }^{4}$, Toshiaki ISHIKAWA', Hirobumi SHIRANE ${ }^{5 !}$, \\ Hiroya UCHIDA ${ }^{5)}$ and Akio TODo"
}

Hemodynamic characteristics were studied by using in vivo vascular imaging techniques in 17 resected early stage hepatocellular carcinoma (e-HCC) by comparing them with 49 resected advanced HCCs (ad-HCC) less than $3 \mathrm{~cm}$ in diameter. In this study, e-HCC was defined as the nodule being uniformly composed of well-differentiated HCC or adenomatous hyperplastic nodule containing welldifferentiated $\mathrm{HCC}$ foci within the nodule. In vivo vascular imaging techniques are as follows; US angiography with intraarterial $\mathrm{CO}_{2}$ microbubbles were performed to assess the tumor arterial vascularity, and CT during arterial portography (CTAP) was performed to assess the portal perfusion within the nodule. Of $17 \mathrm{e}-\mathrm{HCC}$ nodules 5 were hypervascular, 5 were isovascular, 4 were hypovascular, and 3 were vascular spot in hypovascular pattern in contrast to 49 ad-HCC nodules, 43 of which were hypervascular and 6 were isovascular.

Of $14 \mathrm{e}-\mathrm{HCCs}, 9$ nodules showed perfusion defect and 5 did not on CTAP, whereas all 37 ad-HCCs on which CTAP was performed, showed perfusion defect. Forty-one percent (7/17) of e-HCC showed fatty metamorphosis in contrast to $8 \%(4 / 49)$ of ad-HCC. In conclusion, hemodynamic characteristics of e-HCC are summarized as follows. (1) Arterial tumor neovascularization is relatively low. (2) Portal perfusion is present in some of e-HCC cases. (3) Hypoperfusion state both from arterial and portal supply is present in some of e-HCC cases. (4) Vascular spot in hypovascular pattern is characteristic arterial pattern in $\mathrm{AH}$ containing $\mathrm{HCC}$ foci. (5) Fatty metamorphosis may be related with hypoperfusion state of the nodule in e-HCC.

\footnotetext{
"Division of Gastroenterology, Department of Medicine, Kobe City General Hospital (Kobe)

2) Section of Abdominal Ultrasound Service, Kobe City General Hospital (Kobe)

3) First Department of Surgery, Kobe City General Hospital (Kobe)

" Second Department of Surgery, Kobe City General Hospital (Kobe)

5) Department of Pathology, Kobe City General Hospital (Kobe)
} 